CORRECTION

https://doi.org/10.1038/s41586-019-1327-8

\title{
Publisher Correction: Hydrostatic pressure and the actomyosin cortex drive mitotic cell rounding
}

Martin P. Stewart, Jonne Helenius, Yusuke Toyoda,

Subramanian P. Ramanathan, Daniel J. Muller \&

Anthony A. Hyman

Correction to: Nature https://doi.org/10.1038/nature09642,

published online 02 January 2011.

In this Letter, the inset times shown in the DIC and GFP microscopy images in Fig. $1 \mathrm{~b}$ and $\mathrm{c}$ should be in minutes ('min') rather than seconds (' $\mathrm{s}$ ') (that is, $-2 \mathrm{~min}, 6 \mathrm{~min}, 20 \mathrm{~min}, 34 \mathrm{~min}$ and $44 \mathrm{~min}$ for Fig. 1b; $-4 \mathrm{~min}, 2 \mathrm{~min}, 26 \mathrm{~min}, 48 \mathrm{~min}$ and $54 \mathrm{~min}$ for Fig. 1c). The original Letter has not been corrected. 